\title{
Good Corporate Governance Menghasilkan Laporan Keuangan Berkualitas dan Pengaruhnya terhadap Kinerja Keuangan
}

\author{
Arna Suryani ${ }^{1 *}$, Elia Rossa ${ }^{2}$ \\ ${ }^{1}$ Dosen Fakultas Ekonomi Universitas Batanghari Jambi \\ ${ }^{2}$ Dosen Fakultas Ekonomi Universitas Bhayangkara Jakarta \\ *Correspondence email: arna_halim@yahoo.co.id, 2email: elia.rossa@dsn.unbharajaya.ac.id
}

\begin{abstract}
This research aims at finding out and analyzing how good corporate governance produces financial statement which has a certain quality that affects the company's financial performance. The population of this research is a sub-sector of the property listed on the Indonesia Stock Exchange period of 2014-2018, with the selection of samples based on the selected purposive sampling of 16 companies. The data was analyzed by using multiple linear regression by conducting classical assumption tests and hypothesis tests. The results of the research show that good corporate governance measured with the commissioner, foreign ownership and audit committees are simultaneously and significantly affect the financial performance measured by return on asset. Partially the Board of Commissioners have a significant effect on financial performance with a substantial of 1.299. Foreign ownership and audit committees have no significant effect on the financial performance in which the value of sig is $>0.05$. The value of coefficient of determination of $R^{2}$ amounted to $72.9 \%$ showed that Return On Asset variation can be explained by the variation of Board of Commissioners, foreign ownership and audit committee and the remain is $27.1 \%$ which is explained by other factors that do not exist in this research. The results of this research proved that the most dominant variable which has significant effect to the financial performance is the Board of Commissioners. This should be a consideration for the company in the election or designation of the Board of Commissioners to improve implementation of good corporate governance principles in order to improve the company's financial performance.
\end{abstract}

Keywords: Good Corporate Governance, Board of Commissioners, Foreign Ownership Audit Committee, Financial Performance, Return on Asset

\section{PENDAHULUAN}

Laporan keuangan yang dibuat olehperusahaan haruslah menggambarkan kon disi perusahaan yang sebenarnya. Laporan keuangan menjadi alat utama bagi perusahaanu ntuk menyampaikan informasi keuangan mengenai pertanggungjawaban pihak manajemen. Penyampaian informasi melalui laporan keuangan perlu dilakukan untuk memenuhi kebutuhan pemangku kepentingan perusahaan. Praktik corporate governance dapat mendukung kredibilitas informasi keuangan yang disajikan secara transaparan menjadi lebih berkualitas. Corporate governance dapat memberikan perlindungan yang efektif bagi para pemegang saham dan kreditor sehingga dapat memberikan keyakinan bahwa akan memperoleh return yang baik atas dana yang telah diinvestasikan. Shleifer dan Vishny (1997) menyatakan bahwa Corporate governance dianggap sebagai suatu mekanisme yang dapat melindungi pihak minoritas dari eksplorasi yang dilakukan oleh para manajer serta pemegang saham pengendali dengan menekankan pada mekanisme legal. Corporate governance merupakan suatu konsep yang diajukan demi peningkatan kinerja perusahaan melalui supervisi atau monitoring kinerja manajemen dan menjamin akuntabilitas manajemen terhadap stakeholder dengan mendasarkan pada kerangka peraturan (Nasution dan Setiawan, 2007). Jika mekanisme Corporate governance tidak diterapkan atau tidak berfungsi dengan baik dalam perusahaan, maka hal tersebut dapat menurunkan kepercayaan investor dan nilai perusahaan, serta dapat menyebabkan kinerja perusahaan yang kurang baik.

Sesuai dengan Keputusan Direksi Bursa Efek Jakarta No. Kep-305/BEJ/07-2004 butir C mengenai board governance yang terdiri dari dewan komisaris, komite audit, dan sekretaris perusahaan bahwa untuk mencapai good corporate governance, jumlah komisaris independen yang harus ada dalam perusahaan sekurang-kurangnya $30 \%$ dari seluruh anggota dewan komisaris. Dewan komisaris merupakan anggota dewan komisaris yang berasal dari luar perusahaan dan pembentukan dewan komisaris bertujuan untuk memberikan perlindungan terhadap pemegang saham minoritas dalam sebuah perusahaan. Dewan komisaris bertugas untuk memastikan adanya Good Corporate Governance dengan memberikan masukan serta pengawasan kepada Dewan direksi untuk kepentingan perusahaan. Pembentukan komite audit dalam perusahaan juga merupakan salah satu aspek dari adanya good corporate governance. Salah satu tujuan dibentuk komite audit adalah untuk menciptakan iklim yang disiplin dan memperkuat pengendalian yang dapat mengurangi kesempatan terjadinya penyimpangan. Diharapkan dengan adanya komite audit dalam perusahaan akan membuat kinerja perusahaan akan menjadi baik. Jika terjadi peningkatan pada kinerja perusahaan maka investor asing akan menanamkan modalnya di perusahaan tersebut sehingga kepemilikan saham asing dalam perusahaan juga merupakan hal yang penting dalam menilai kinerja perusahaan. Selain itu, komite audit juga dapat meningkatkan kredibilitas informasi keuangan baik secara langsung yang dapat mendukung praktik 
Arna Suryani dan Elia Rossa, Good Corporate Governance Menghasilkan Laporan Keuangan Berkualitas dan Pengaruhnya terhadap Kinerja Keuangan

corporate governance melalui pelaporan keuangan yang disajikan secara transparan (Francis et.al, 2003 dan Sloan, 2001 dalam Haat, 2008).

Manajemen dituntut untuk dapat menyajikan laporan keuangan yang berkualitas karena laporan keuangan sering dijadikan dasar untuk penilaian kinerja perusahaan. Kinerja keuangan merupakan patokan utama untuk mengukur baik atau tidaknya kinerja perusahaan. Penilaian kinerja keuangan suatu perusahaan merupakan salah satu cara yang dapat dilakukan oleh manajemen agar dapat memenuhi kewajibannya terhadap para penyandang dana dan juga untuk mencapai tujuan yang telah ditetapkan perusahaan. Penilaian kinerja perusahaan yang ditimbulkan sebagai akibat dari proses pengambilan keputusan manajemen,merupakan persoalan yang kompleks karena menyangkut efektivitas pemanfaatan modal dan efisiensi dari kegiatan perusahaan yang menyangkut nilai serta keamanan dari berbagai tuntutan yang timbul terhadap perusahaan. Indikator kinerja keuangan perusahaan dapat dilihat dari seberapa besar kemampuan perusahaan untuk mendapatkan laba. Return on asset (ROA) merupakan rasio profitabilitas sering digunakan untuk menilai kinerja keuangan. ROA dapat membantu perusahaan yang telah menjalankan praktik akuntansi dengan baik untuk dapat mengukur efisiensi penggunaan modal yang menyeluruh, yang sensitif terhadap setiap hal yang mempengaruhi keadaan keuangan perusahaan sehingga dapat diketahui posisi perusahaan terhadap industri. Hal ini merupakan salah satu langkah dalam perencanaan strategi. ROA adalah rasio yang digunakan untuk mengukur kemampuan perusahaan dalam menghasilkan laba yang berasal dari aktivitas investasi (Mardiyanto, 2009). Beberapa hasil penelitian antara lain Imas Kusumandari (2016) yang menyatakan bahwa bahwa ukuran dewan komisaris dan ukuran dewan direksi berpengaruh signifikan terhadap ROA, yang terdaftar di Bursa Efek Indonesia Tahun 2011-2015. Hermiyetti dan Erlinda Katlanis (2016) yang menyatakan bahwa secara parsial kepemilikan asing memiliki pengaruh positif dan signifikan terhadap kinerja keuangan perusahaan, dan hasil penelitianYuda Adestian (2017) yang menyatakan bahwa secara parsial komite audit tidak berpengaruh terhadap kinerja perusahaan perbankan yang listing di Bursa Efek Indonesia (BEI) tahun 2012-2014. Tujuan dalam penelitian ini adalah untuk mengetahui dan menganalisis pengaruh dewan komisaris, kepemilikan asing, dan komite audit terhadap kinerja keuangan pada perusahaan sub sektor Property yang terdaftar di Bursa Efek Indonesia periode 2014-2018.

\section{Landasan Teori}

\section{Good Corporate Governance (GCG)}

Corporate governance menurut organitazation for economic corporate and development (OECD, 2004) didefenisikan sebagai sistem yang dipergunakan untuk mengarahkan dan mengendalikan kegiatan bisnis perusahaan. Corporate governance mengatur pembagian tugas, hak dan kewajiban mereka yang yang berkepentingan terhadap suatu perusahaan, termasuk para pemengang saham, dewan pengurus, manajer, dan semua anggota stakeholders non pemengang saham. Perusahaan harus selalu memperhatikan kepentingan semua pemengang saham yang berasaskan atas kewajaran dan kesetaraan. Salah satu tujuan dari diterapkannya corporate governance adalah laporan keuangan perusahaan yang dihasilkan oleh manajemen disajikan dengan prinsip akuntabilitas dan transparansi. Laporan keuangan merupakan hal yang penting bagi pengguna informasi karena dari laporan keuangan tersebut dapat mempengaruhi keputusan. Untuk meningkatkan keakuratan dan kehandalan dari informasi keuangan yang digunakan oleh investor dalam rangka pengambilan keputusan investasi, maka diterapkanlah corporate governance. Agar corporate govenance tersebut berjalan dengan efektif dan efisien, maka dibentuklah suatu sistem dan susunan tugas dan wewenang komite audit dan dewan komisaris.

Komite audit yang beranggotakan komisi independen diharapkan mampu melaksanakan tugas utamanya yang berkaitan dengan kebijakan akuntansi perusahaan, pengawasan internal, dan sistem pelaporan keuangan sehingga dapat mengurangi kecurangan dan kemungkinan manipulasi. Dengan adanya komite audit diharapkan dapat meminimalisir tindakan pelanggaran yang dilakukan oleh manajemen perusahaan. Sedangkan komisaris independen adalah anggota dewan komisaris yang tidak terafiliasi dengan direksi, anggota dewan komisaris lainnya dan pemengang saham pengendali, serta bebas dari hubungan bisnis atau hubungan lain yang dapat mempengaruhi kemampuannya untuk bertindak independen atau bertindak semata-mata demi kepentingan perusahaan. Misi komisaris independen dalah mendorong terciptanya iklim yang lebih objektif dan menempatkan kesetaraan (fairness) diantara berbagai kepentingan termasuk kepentingan perusahaan dan kepentingan stakeholder sebagai prinsip utama dalam pengambilan keputusan oleh dewan komisaris (Ujiyantho dan Pramuka, 2007).Tujuan Pembentukan komite audit dan dewan komisaris ini merupakan suatu bentuk penerapan prinsip-prinsip good corporate governance dalam perusahaan. Komite audit dan Komisaris independen memiliki tanggungjawab pokok untuk mendorong diterapkannya prinsip tata kelola perusahaan yang baik (good corporate governance) di dalam perusahaan melalui pemberdayaan komite audit dan dewan komisaris agar dapat melakukan tugas pengawasan dan pemberi nasehat kepada direksi secara efektif dan lebih memberikan nilai tambah bagi perusahaan. Penerapan tatakelola perusahaan diharapkan dapat meminimalisir praktik manajemen laba dalam suatu perusahaan. 


\section{Kinerja Keuangan}

Laporan keuangan sering dijadikan dasar untuk penilaian kinerja perusahaan (Kieso, 2015).Analisis rasio keuangan merupakan metode umum yang digunakan untuk mengukur kinerja perusahaan di bidang keuangan. Salah satu jenis laporan keuangan yang mengukur keberhasilan operasi perusahaan untuk suatu periode tertentu adalah laporan laba rugi. Akan tetapi angka laba yang dihasilkan dalam laporan laba rugi sering kali dipengaruhi oleh metode akuntansi yang digunakan, sehingga laba yang tinggi belum tentu mencerminkan kas yang besar. Rasio profitabilitas mengukur kemampuan perusahaan untuk menghasilkan laba. Rasio ini membantu perusahaan dalam mengontrol penerimaannya.Return on assets (ROA) sebagai salah satu ratio profitabilitas dapat menjadi salah satu dasar pengukuran kinerja keuangan. Menurut Hanafi dan Halim (2003), Return on Assets (ROA) merupakan rasio keuangan perusahaan yang berhubungan dengan profitabilitas mengukur kemampuan perusahaan menghasilkan keuntungan atau laba pada tingkat pendapatan, aset dan modal saham tertentu. Dengan mengetahui ROA, kita dapat menilai apakah perusahaan telah efisien dalam menggunakan aktivanya dalam kegiatan operasi untuk menghasilkan keuntungan.

\section{METODE}

Objek penelitian ini adalah good corporate governance yang diukurdengan dewan komisaris, kepemilikan asing dan komite audit, dan kinerja keuangan yang diukurd engan return on Asset. Data sekunder bersumber dari ICMD, serta berbagai macam literatur lainnya. Populasi dalam penelitian ini adalah perusahaan sub sektor property yang terdaftar di bursa efek Indonesia periode 2014-2018 dengan sampel dipilih berdasarkan purposive sampling terpilih sebanyak 16 perusahaan. Metoda penelitian yang digunakan dalam penelitian ini merupakan penelitian yang menjelaskan explanatory research (Cooper, 2008). Metoda penelitian explanatory dilakukan untuk memperoleh kejelasan fenomena yang terjadi di tataran empiris (real world) dan berusaha untuk mendapatkan jawaban (verificative). Analisis data melalui pengujian. Metode analisis menggunakan alat analisis regresi linier berganda dengan uji asumsi klasik dan pengujian hipotesis melalui Uji Parsial (Uji t) dan uji Simultan (Uji F) dan uji Determinasi. Persamaan regresi dalam penelitian ini dapat dirumuskan sebagai berikut:

$Y=\alpha+\beta_{1} X_{1}+\beta_{2} X_{2}+\beta_{3} X_{3}+e$

Keterangan: $\mathrm{Y}=$ Kinerja keuangan ROA; $\mathrm{X}_{1} \quad=$ Dewan Komisaris; $\mathcal{E}=$ error; $\mathrm{A}=$ Konstanta; $\mathrm{X}_{2}=$ Kepemilikan Asing; $\beta 1-\beta 3=$ Koefisien regresi; $X_{3}=$ Komite Audit

Tabel. 1

Operasional Variabel

\begin{tabular}{|c|c|c|}
\hline Variabel & Indikator & Ukuran \\
\hline \multirow[t]{3}{*}{$\begin{array}{l}\text { Good Corporate } \\
\text { Governance }\end{array}$} & $\begin{array}{c}\text { DewanKomisaris } \\
\left(\mathrm{X}_{1}\right)\end{array}$ & $\begin{array}{l}\text { Dewan komisaris diukur dengan jumlah dewankomisaris yang } \\
\text { ada pada perusahaan sampel }\end{array}$ \\
\hline & KepemilikanAsing $\left(\mathrm{X}_{2}\right)$ & $\begin{array}{l}\text { Kepemilikan asing diukur dengan jumlah kepemilikan asing dibagi } \\
\text { dengan jumlah kepemilikan internal. }\end{array}$ \\
\hline & $\begin{array}{l}\text { Komite Audit } \\
\qquad\left(\mathrm{X}_{3}\right)\end{array}$ & $\begin{array}{l}\text { Komite audit diukur dengan jumlah komite audit yang ada pada } \\
\text { perusahaan sampel }\end{array}$ \\
\hline Kinerja & Return On Asset & Laba setelah pajak \\
\hline Keuangan & $(\mathrm{Y})$ & Total Aktiva \\
\hline
\end{tabular}

\section{HASIL}

Salah satu syarat agar pengujian regresi berganda tidak terjadi bias adalah uji asumsi klasik terdiri dari empat pengujian yaitu, uji normalitas data, heteroskedastisitas, uji autokorelasi dan uji multikolinearitas. Hasil pengujian asumsi klasik diperoleh data berdistribusi normal, tidak terdapat masalah multikolinieritas, tidak terjadi autokorelasi dan tidak terjadi heteroskedastisitas. Semua nilai probabilitas koefisien korelasi yang diperoleh adalah signifikan yakni sig. $(2$ tailed $)>0.05$ menunjukkan bahwa korelasi setiap variabel adalah ada hubungan yang signifikan. Regresi linear berganda dilakukan untuk mengukur seberapa besar pengaruh variabel independen terhadap variabel dependen. Hasil persamaan regresi yang diolah dengan menggunakan SPSS versi 21 dapat dilihat pada tabel berikut :

Tabel 2

Regresi Linear Berganda

\begin{tabular}{|l|l|r|r|r|}
\hline \multirow{2}{*}{ Model } & \multicolumn{2}{|c|}{ Unstandardized Coefficients } & \multicolumn{1}{c|}{ Standardized Coefficients } \\
\cline { 3 - 5 } \multicolumn{1}{|l|}{1} & B & Std. Error & Beta \\
\hline \multirow{3}{*}{1} & (Constant) & $-7,499$ & 3,648 &, 665 \\
\cline { 2 - 5 } & Dewan_Komisaris & 1,299 &, 271 &, 236 \\
\cline { 2 - 5 } & K_Asing &, 098 &, 059 &, 247 \\
\cline { 2 - 5 } & Komite_Audit & 2,323 & 1,257 & \\
\hline
\end{tabular}


Arna Suryani dan Elia Rossa, Good Corporate Governance Menghasilkan Laporan Keuangan Berkualitas dan Pengaruhnya terhadap Kinerja Keuangan

Hasil pengelolaan data tersebut didapatkan persamaan regresi linear sebagai berikut :Y $=-7,499+1,299 \mathrm{X}_{1}+$ $0,098 \mathrm{X}_{2}+2,323 \mathrm{X}_{3}+\mathrm{e}$, maka dapat di interprestasikan sebagai berikut :

1. Nilai konstanta $(\alpha)$ sebesar -7,499 memberikan arti bahwa apabila Dewan Komisaris $\left(X_{1}\right)$, Kepemilikan Asing $\left(\mathrm{X}_{2}\right)$, dan Komite Audit $\left(\mathrm{X}_{3}\right)$ bernilai 0, maka nilai Return On Asset (Y) sebesar -7,499.

2. Nilai koefisien regresi linear variabel Dewan Komisaris $\left(\mathrm{X}_{1}\right)$ sebesar 1,299 memberikan arti bahwa Dewan Komisaris $\left(\mathrm{X}_{1}\right)$ berpengaruh positif terhadap Return On Asset (ROA). Hal ini menunjukan jika Dewan Komisaris $\left(\mathrm{X}_{1}\right)$ meningkat 1\% maka Return On Asset (ROA) akan naik sebesar 1,299\% dengan asumsi variabel independen lainnya tetap.

3. Nilai koefisien regresi variabel Kepemilikan Asing $\left(\mathrm{X}_{2}\right)$ sebesar 0,098 memberikan arti bahwa Kepemilikan Asing $\left(\mathrm{X}_{2}\right)$, berpengaruh positf terhadap Return On Asset (ROA). Hal ini menunjukan jika Kepemilikan Asing $\left(\mathrm{X}_{2}\right)$ meningkat 1\% maka Return On Asset (ROA) akan turun sebesar 0,098\% dengan asumsi variabel independen lainnya tetap.

4. Nilai koefisien regresi variabel Komite Audit $\left(\mathrm{X}_{3}\right)$ sebesar 2,323 memberikan arti bahwa Komite Audit $\left(\mathrm{X}_{3}\right)$ berpengaruh positif terhadap Return On Asset (ROA). Hal ini menunjukan jika Komite Audit $\left(\mathrm{X}_{3}\right)$ meningkat $1 \%$ maka Return On Asset (ROA) akan naik sebesar 2,323\% dengan asumsi variabel independen lainnya tetap.

\section{Uji Hipotesis}

Uji F pada dasarnya digunakan untuk melihat apakah semua variabel independen yang dimasukan dalam model mempunyai pengaruh secara bersama-sama atau simultan terhadap variabel dependen. Berikut ini hasil Uji F yang diolah menggunakan SPSS versi 21 yang disajikan dalam tabel berikut ini :

Tabel 3

Uji Simultan (Uji F)

\begin{tabular}{|l|l|r|r|r|r|r|}
\hline \multicolumn{2}{|l|}{ Model } & Sum of Squares & Df & Mean Square & F & Sig. \\
\hline \multirow{3}{*}{1} & Regression & 164,684 & 3 & 54,895 & 14,323 &, $000^{\mathrm{b}}$ \\
\cline { 2 - 7 } & Residual & 61,321 & 76 & 3,833 & & \\
\cline { 2 - 8 } & Total & 226,005 & 79 & & & \\
\hline
\end{tabular}

Sumber: data olahan

Tabel 3 di atas dapat dilihat $F_{\text {hitung }}$ besar dari $\mathrm{F}_{\text {tabel }}(14,323>3,24)$ dan dengan membandingkan besarnya taraf signifikan 0,000 >0,05 berarti dapat dikatakan bahwa ada pengaruh positif yang signifikan antara variabel Dewan Komisaris, Kepemilikan Asing dan Komite Audit secara bersama-sama terhadap Kinerja Keuangan pada Sub Sektor Properti yang terdaftar di Bursa Efek Indonesia (BEI) periode 2013-2017. Secara simultan Dewan Komisaris, Kepemilikan Asing, dan Komite Audit berpengaruh secarasimultandansignifikan terhadap kinerja keuangan, sehingga hipotesis satu diterima. Hasil Uji secara parsial (t) disajikan dalam tabel berikut ini:

Tabel 4

Uji Parsial (Uji t)

\begin{tabular}{|c|c|c|c|c|c|}
\hline \multirow[t]{2}{*}{ Model } & \multicolumn{2}{|c|}{ Unstandardized Coefficients } & Standardized Coefficients & \multirow[t]{2}{*}{$\mathrm{t}$} & \multirow[t]{2}{*}{ Sig. } \\
\hline & $\mathrm{B}$ & Std. Error & Beta & & \\
\hline (Constant) & $-7,499$ & 3,648 & & $-2,056$ & ,057 \\
\hline Dewan_Komisaris & 1,299 & 271 & ,665 & 4,794 &, 000 \\
\hline K_Asing & ,098 &, 059 & 236 & 1,668 &, 115 \\
\hline Komite_Audit & 2,323 & 1,257 & ,247 & 1,847 & ,083 \\
\hline
\end{tabular}

Sumber: data olahan

Tabel 4 di atas dapat dilihat Nilai thitung variabel Dewan Komisaris sebesar 4,794 dan $t_{\text {tabel }}$ sebesar 2,11991. Dari hasil perbandingan tersebut dapat dikatakan bahwa nilai $t_{\text {hitung }}$ lebih besar dari nilai $t_{\text {tabel }}\left(t_{\text {hitung }}>t_{\text {tabel }}\right)$ maka artinya ada pengaruh secara signifikan antara variabel dewan komisaris terhadap kinerja keuangan, sehingga hipotesis dua ditolak. Nilai $t_{\text {hitung }}$ variabel Kepemilikan Asing sebesar 1,668 dan $t_{\text {tabel }}$ sebesar 2,11991 maka nilai $t_{\text {hitung }}<\mathrm{t}_{\text {tabel, }}$, berarti tidak ada pengaruh secara signifikan antara variabel Kepemilikan Asing terhadap kinerja keuangan, sehingga Hitopesis tiga ditolak. Nilai $t_{\text {hitung }}$ variabel Kepemilikan Institusional sebesar 1,847 dan $t_{\text {tabel }}$ sebesar 2,1199 maka nilai $t_{\text {hitung }}<\mathrm{t}_{\text {tabel }}$ yang artinya tidak ada pengaruh secara signifikan antara variabel Komite Audit terhadap kinerja keuangan sehingga Maka Hipotesis empat ditolak. 
Arna Suryani dan Elia Rossa, Good Corporate Governance Menghasilkan Laporan Keuangan Berkualitas dan Pengaruhnya

Tabel 5

Hasil Uji Koefisien Determinasi $\left(\mathrm{R}^{2}\right)$

\begin{tabular}{|l|r|r|r|r|r|}
\hline Model & $\mathrm{R}$ & $\mathrm{R}$ Square & Adjusted R Square & Std. Error of the Estimate & Durbin-Watson \\
\hline 1 &, $854^{\mathrm{a}}$ &, 729 &, 678 & 1,95769 & 2,288 \\
\hline
\end{tabular}

Sumber: data olahan

Berdasarkan Tabel 5 diatas diperoleh angka $R$ square sebesar 0,729 hal itu berarti bahwa variasi perubahan $\mathrm{Y}$ dipengaruhi oleh perubahan $\mathrm{X}_{1}, \mathrm{X}_{2}$, dan $\mathrm{X}_{3}$, sebesar $72,9 \%$. Jadi besarnya pengaruh Dewan Komisaris, Kepemilikan Asing, dan Komite Audit terhadap kinerja keuangan Return On Asset (ROA) 72,9\%. Sedangkan sisanya sebesar $27,1 \%$ dipengaruhi oleh faktor lain diluar penelitian ini.

\section{SIMPULAN}

Berdasarkan hasil penelitian yang dilakukan pada Sub Sektor Properti yang terdaftar di Bursa Efek Indonesia (BEI) periode 2014-2018, maka dapat disimpulkan secara simultan dewan komisaris, kepemilikan asing dan komite audit berpengaruh signifikan terhadap kinerja keuangan. Secaraparsial Dewan Komisaris berpengaruh signifikan terhadap kinerja keuangan. Kepemilikan Asing dan komite audit tidak berpengaruh signifikan terhadap kinerja keuangan. Nilai koefisien determinasi $\mathrm{R}^{2}$ sebesar 72,9\% menunjukan bahwa variasi Return On Asset (ROA) dapat dijelaskan oleh variasi Dewan Komisaris, Kepemilikian Asing dan Komite Audit dan sisanya yaitu 27,1\% dijelaskan oleh faktor lain yang tidak ada dalam penelitian ini. Variabel yang paling dominan mempengaharui ROA adalah variabel Dewan Komisaris.

\section{DAFTAR PUSTAKA}

Adestian, Yuda. 2015. Pengaruh Dewan Komisaris, Dewan Direksi, Dewan Komisaris Independen, Komite Audit dan Ukuran perusahaan pada kinerja perusahaan perbankan yang Listing di BEI padatahun 2012-2014. Jurnal Ekonomi dan Bisnis. Universitas Dian Nurwantoro.

Arafat, Wilson, Mohamad Fajri MP, Smart Strategy for 360 degree GCG (Good Corporate Governance) (October 2009). Skyrocketing Publisher. ISBN 978-979-18098-1-8.

Arafat, Wilson, How To Implement GCG Effectively (July 2008). Skyrocketing Publisher.

Adrian Sutedi, 2011, Good Corporate Governance, Jakarta sinar grafika

Amin Tijaya Tunggal dan Imam Sjahputra Tunggal. 2002. Memahami Konsep Good Corporate Governance, Jakarta,Havarindo.

CheHaat, MohHasan, et.al. 2008. Corporate Governance, Transparency and Performance of Malaysian Companies, Malaysian of Auditing Journal. Vol. 23 No.8.

Cooper, Donald. R dan Pamela S. Schindler. 2008. Business Reseach Method. Edisikesepuluh. New york: McGrawHill.

E. Kieso, Donald, Jerry J, Weygandt and Teery D. Walfield. 2015. Intermediate accounting, Edisi 13. Jakarta: Erlangga

FCGI. 2011. Peranan Dewan Komisaris dan Komite Audit dalam Pelaksanaan Good Corporate Governance (Tata Kelola Perusahaan). Edisi 2, Jilid II, FCGI.

Ghozali, Imam. 2006. Aplikasi Analisis Multivariate Dengan Program SPSS.Cetakan Keempat. Semarang: Badan Penerbit Universitas Diponegoro.

Hamdani. 2016. "Good Corporate Governance", Buku Tinjauan Etika dalam praktik bisnis, Vol 1.

Hermiyetti, dan Erlinda Katlanis. 2016. Pengaruh Kepemilikan mnajerial, Kepemilikan Institusional, Kepemilikan Asing dan Komite Audit terhadap Kinerja Keuangan Perusahaan. Media Riset Akuntansi, Vol.6 No.2.

Hanafi, Mamduh dan Abdul Halim. 2003. Analisis Laporan Keuangan. Edisi Revisi. Yogyakarta: UPP AMP YKPN

Keputusan Direksi Bursa Efek Jakarta No. Kep-305/BEJ/07-2004 butir C mengenai board governance

Mardiyanto, Handoko. 2009. Intisari Manajemen Keuangan. Jakarta: PT Gramedi Widiasarana Indonesia (Grasindo)

Nasution, M dan Setiawan, D. 2007. Pengaruh Corporate Governance terhadap Manajemen Laba di Industry Perbankan Indonesia. Symposium Nasional Akuntansi X. Makassar, Tanggal 26-28 Juli 2007.

Shleifer, A dan R.W. Vishny. 1997. A Survey of Corporate Governance. Journal of finance. 52 (2), 737-783.

Suryani, Arna dan Eva Herianti. 2015. Pengaruh PengungkapanTanggung jawab Sosial Perusahaan terhadap Koefisien Respon Laba dan Manajemen Laba. Simposium Nasional Akuntansi (SNA) XVIII, Medan. 2015.

Suryani, Arna, et.al. 2019. Disclosure of Sosial Responsibility, Profitabilitay to Improve the Company Value. KnE Social Sciences, 1008-1016.

Ujiyantho dan Pramuka. 2007. Mekanisme Corporate Governance, Manajemen Laba dan Kinerja Keuangan. (Studi Pada Perusahaa go public Sektor Manufaktur). Jurnal Simposium Akuntansi Nasional X. Massar. 